$7-2010$

\title{
Failure Literacy in Structural Engineering
}

Norbert J. Delatte

Cleveland State University, n.delatte@csuohio.edu

Follow this and additional works at: https://engagedscholarship.csuohio.edu/encee_facpub

Part of the Structural Engineering Commons

How does access to this work benefit you? Let us know!

Publisher's Statement

NOTICE: this is the author's version of a work that was accepted for publication in Engineering Structures. Changes resulting from the publishing process, such as peer review, editing, corrections, structural formatting, and other quality control mechanisms may not be reflected in this document. Changes may have been made to this work since it was submitted for publication. A definitive version was subsequently published in Engineering Structures, 32, 7, (07-01-2010); 10.1016/j.engstruct.2009.12.015

\section{Original Citation}

Delatte, N. (2010). "Failure literacy in structural engineering." Eng.Struct., 32(7), 1952-1954.

This Article is brought to you for free and open access by the Civil and Environmental Engineering at EngagedScholarship@CSU. It has been accepted for inclusion in Civil and Environmental Engineering Faculty Publications by an authorized administrator of EngagedScholarship@CSU. For more information, please contact library.es@csuohio.edu. 


\title{
Failure literacy in structural engineering
}

\author{
Norbert Delatte* \\ Civil \& Environmental Engineering Department, Stilwell Hall Room SH 121, Euclid Avenue at East 24th Street, Cleveland State University, Cleveland, OH 44115, United States
}

\section{Introduction}

Learning from failures is an essential element of structural engineering, as well as many other engineering professions. As retired Professor Oswald Rendon-Herrero of Mississippi State University has observed, "What sort of doctor would study only healthy persons?" [1]. The author coined the term "failure literacy" for the concept that engineering students and practicing engineers must possess a working knowledge of landmark failures and of how failures have informed and changed the practice of engineering [2,3]. "This literacy entails knowing about the critical historical failure cases that have shaped the profession, not merely the surface technical details, but the environment, the communications difficulties and the procedural issues" [2]. All engineers, and more particularly structural engineers, should be failure literate. The objective of this paper is to review the purpose and importance of failure literacy, as well as implementation of failure literacy in the civil engineering university curriculum.

In some engineering disciplines, such as mechanical, aerospace, and electrical engineering, it is possible to build and thoroughly test prototypes before putting a design into production. That is not practical for structures. It is difficult and expensive even to test a small part of a building or bridge.

Therefore, since it is not possible to thoroughly test a structural design in advance, it is important to know what failure modes are likely to apply through knowledge of past failures of similar designs and systems. It is important to consider history and failure analysis in the context of design. Design can be viewed very simply as a two-step process:

1. Figure out everything that can possibly go wrong.

2. Make sure that everything that can possibly go wrong does not happen.

The first step of the two is the more difficult. It is hard to know, in advance, what all the potential modes of failure are, and, more importantly, what the governing mode of failure is likely to be. However, this knowledge is necessary for a successful design. Thus, engineers must be knowledgeable and "literate" about past failures and patterns of failure. This includes a working knowledge of landmark structural failures.

\section{Landmark structural failures}

An earlier paper [2] listed a series of landmark structural failures, mostly from a US perspective. The structural failures occurred in the US, unless otherwise noted below, and have often been well documented in investigation reports and technical papers. These are, in chronological order,

- The Quebec bridge collapse, 1907 (Canada) [4-6].

- The Tacoma Narrows bridge collapse, 1940.

- The Point Pleasant/Silver Bridge collapse, 1967 [7].

- The Ronan Point building collapse, 1968 (UK) $[8,9]$.

- The 2000 Commonwealth Avenue building collapse, 1971 [10].

- The Bailey's Crossroads building collapse, 1973.

- The Hartford Civic Center building collapse, 1978 [11].

- The Willow Island power plant cooling tower collapse, 1978.

- The Harbour Cay Condominium collapse, 1981.

- The Hyatt Regency walkway collapse, 1981 [12].

- The Mianus River Bridge collapse, 1983, and

- The L'Ambiance Plaza building collapse, 1987 [13]. 
In addition to technical issues, concepts such as professional and ethical responsibility are highlighted by the cases. There are also a number of recent international cases of interest. These include the Sampoong Super Store collapse in Seoul, Republic of Korea [14], and the Laval, Quebec, Canada bridge overpass collapse [15].

This list, unfortunately, is a living document that will expand as more failures occur. Thorough forensic investigations are vital to capture the lessons from the unfortunate occurrences.

\section{Typical case study elements}

Typical elements of the failure case studies are [3]:

- Introduction.

- Description of the design and construction of the project.

- Narrative describing the failure.

- Discussion of any investigations undertaken and the results. This may include a review of who the investigators were, who hired them (and why), and any limits on the scope of the investigation.

- Technical lessons learned. Special attention is paid to any changes in engineering codes or procedures.

- Procedural and ethical lessons learned, particularly legal repercussions.

- Educational aspects of the case.

- A detailed reference list including investigation reports, published papers, and newspaper and journal accounts.

\section{Developing failure literacy worldwide}

In the US, the National Science Foundation (NSF) and the American Society of Civil Engineers Technical Council on Forensic Engineering (ASCE TCFE) have been providing funding and support for promoting failure literacy in engineering education through various projects for over a decade. Some early efforts were documented in a 2002 state-of-the-art paper [16].

Starting in 2003, a series of half-day and one-day workshops on integrating failure case studies in engineering education has been held annually at a number of different locations in the US [17]. These workshops were geared toward university faculty in civil engineering and related disciplines, with a total of over 100 participants over the years. Under the auspices of ASCE TCFE, a half-day workshop was held in London, UK, in December 2008 and a twoday extended workshop was held in Cartago, Costa Rica, in July 2009.

After a few years, the question arose as to whether the incorporation of failure case studies into engineering education had a measurable beneficial impact. Fortunately, the NSF funded research into this issue, starting in 2005. Failure case studies were incorporated into courses at Cleveland State University in Strength of Materials and Construction Planning and Estimating, in the second and fourth year of the curriculum, respectively [18]. Students in the classes took part in surveys and focus groups, using questions geared to the US Accreditation Board for Engineering and Technology (ABET) accreditation standards [19].

In the Strength of Materials course, the case studies included the 1907 Quebec bridge collapse and the 1967 Point Pleasant bridge collapse, as well as others. Students were provided with copies of the relevant technical papers concerning these cases [6,7]. In the Construction Planning and Estimating course, the cases included the economic problems of the Montreal Olympics of 1976 and the Hyatt Regency walkway collapse of 1981.

Survey results were reported on a 1-5 scale, with 5 the most favorable result (strongly agree). In response to the 2007 surveys, the students reported that the failure case studies contributed to (averages in two different courses) [18]:
- ability to apply knowledge of mathematics, science, and engineering $(4.33,4)$;

- understanding of professional and ethical responsibility (4.33, 4.75);

- broad education necessary to understand the impact of engineering solutions in a global and social context (4.22, 3.75);

- recognition of the need for, and an ability to engage in, life-long learning $(3.67,4.25)$;

- knowledge of contemporary issues $(4,4)$; and

- ability to use the techniques, skills, and modern engineering tools necessary for engineering practice $(3.67,4.25)$.

The surveys were repeated in 2008 and the results were similar. These questions were taken verbatim from the ABET accreditation standards [19]. The students also agreed that the case studies made substantial contributions to their interest in and understanding of the course material. The focus groups identified additional benefits to the use of case studies. Students observed that the cases helped build engineering identity, and provided historical understanding. They also reported that the cases made the technical information relevant and linked theory to practice [18].

\section{Resources for failure literacy}

The research into use of failure cases also produced a book, Beyond Failure [3], and a project web site, http://matdl.org/ failurecases/ [20]. The project web site was prepared along with the book. The web site includes a master bibliography, a discussion of the faculty case study workshops, a chronological listing of case studies, a list of course pages, and information for faculty. This list is also subdivided into building, bridge, dam, and other case studies. Many of the cases, such as the Quebec bridge, can be used in many different courses, and thus show up on several web pages. The web site is not merely a web version of the book. The book has more detail about many of the cases. There are also short cases on the web site which are not in the book. The two are intended to complement each other.

Although these resources were developed for educators and students, they are also of considerable interest and value for practicing engineers. In many US licensing jurisdictions, registered professional engineers are required to attend a minimum of $15 \mathrm{~h}$ per year of continuing education to maintain licensure. This provides a means to embed failure literacy into the engineering profession.

\section{Summary and conclusions}

The history of the development of practice in many engineering disciplines is, in large part, the story of failures, both imminent and actual, and of the changes to designs, standards and procedures made as the result of timely interventions or forensic analyses. In addition to technical issues, concepts such as professional and ethical responsibility are highlighted by the cases. Pilot studies have been carried out over several semesters in order to assess the use of failure case studies in civil engineering and engineering mechanics courses. A number of educational resources have been developed to make it easier for engineering students and practicing engineers to learn from failures.

Although engineering is typically regarded as technical work, in reality it is a form of communication. Engineers communicate their vision of a structure and how it should perform through drawings and specifications. Thus, expanding failure literacy also includes understanding how errors in communication and management can be as dangerous as technical errors.

Failure literacy builds a broad awareness of all of the things that can go wrong on a construction project. Awareness brings care, and hopefully that care and caution will enable the engineer and the project team to avoid future failures. This is necessary not only for design, but also for the construction and maintenance phases of projects. 


\section{Acknowledgements}

This work was supported by the US National Science Foundation through several grants, DUE 0127419, DUE-0536666, and DUE-0919487. Funding and support have also been provided by the Technical Council on Forensic Engineering of the American Society of Civil Engineers. Opinions expressed are solely those of the author and not of the National Science Foundation or the American Society of Civil Engineers.

\section{References}

[1] Rendon-Herrero Oswald, personal communication.

[2] Delatte NJ. Learning from failures. Civil Engineering Practice, J Boston Soc Civ Eng Sect, ASCE 2006;21(2):21-38. Boston, MA, F/W 2006.

[3] Delatte NJ. Beyond failure: Forensic case studies for civil engineers. Reston (VA): ASCE Press; 2009.

[4] Holgate Henry, Kerry JGG, Galbraith John. Royal Commission Quebec Bridge Inquiry Report. S.E. Dawson printer to the King Ottawa, 1908.

[5] Middleton William D. Bridge at Quebec. Indiana: Indiana University Press; 2001.

[6] Pearson C, Delatte N. The collapse of the Quebec Bridge, 1907. J Perform Constr Facil, ASCE 2006.

[7] Lichtenstein A. The silver bridge collapse recounted. J Perform Constr Facil, ASCE 1993;7(4):249-61.

[8] Griffiths H, Pugsley AG, Saunders O. Report of the inquiry into the collapse of flats at Ronan Point, Canning Town. UK: Her Majesty's Stationery Office; 1968.

[9] Pearson C, Delatte N. The Ronan Point apartment tower collapse and its effect on building codes. ASCE J of Perf of Const Facil 2005;19(2):172-7.

[10] King S, Delatte N. Collapse of 2000 Commonwealth avenue: A punching shear case study. J Perform Constr Facil, ASCE 2004;18(1):54-61.

[11] Martin R, Delatte N. Another look at the Hartford civic center coliseum collapse. J Perform Constr Facil, ASCE 2001;15(1).

[12] Luth GP. Chronology and context of the Hyatt Regency collapse. J Perform Constr Facil, ASCE 2000;14(2).

[13] Martin R, Delatte N. Another look at the L'Ambiance Plaza collapse. J Perform Constr Facil, ASCE 2000;14(4).

[14] Gardner NJ, Huh J, Chung L. Lessons from the Sampoong department store collapse. Cement Concr Composit 2002;24:523-9.

[15] Commission of Inquiry into the Collapse of a Portion of the de la Concorde Overpass: Oct. 3, 2006-Oct. 15, 2007, Report. Canada: Government of Quebec. 2007.

[16] Delatte N, Rens KL. Forensics and case studies in civil engineering education: State-of-the-art. J Perform Constr Facil, ASCE 2002;16(3).

[17] Delatte N, Bosela P, Rens K, Carper K, Sutterer K. Findings from workshops on failure case studies in the civil engineering and engineering mechanics curriculum. In: Proceedings of ASEE annual conf. \& expo., 2007.

[18] Delatte N, Bosela P, Bagaka's J, Sutton R. Assessing the impact of case studies on the civil engineering and engineering mechanics curriculum, final report. In: Proceedings of ASEE annual conf. \& expo., 2009.

[19] Accreditation Board for Engineering and Technology, Inc. (ABET) (2007) Engineering Accreditation Commission, Criteria for Accrediting Engineering Programs, Baltimore, MD.

[20] Web site Failure Case Studies: Civil engineering and engineering mechanics. http://matdl.org/failurecases/. 